\title{
Strain-Specific Differences in the Vermian Granular Layer of Albino Rats ${ }^{1}$
}

\author{
H. Heinsen, Y. L. Heinsen \\ Abteilung Anatomie der Rheinisch-Westfälischen Technischen Hochschule, Aachen BRD
}

Key Words. Albino rats · Cerebellum · Granular layer · Quantitative anatomy · Strain differences

\begin{abstract}
Foliation of the cerebella of Sprague-Dawley rats (strain Han:SPRD) is more advanced than in Wistar rats (strain Chbb:THOM). The differences expressed as length of the granular layer in median sections were significant in lobules VIa, VIII, IX and X. The length of the other vermian lobules is generally higher in the former strain. With regard to the volume of the granular layer, the situation is reversed, indicating that the lateral extent and thickness of vermian lobules in Wistar rats (strain Chbb:THOM) is generally larger. These quantitative differences may express differences in cerebellar microcircuitry and fibre connections in the cortex of Wistar and Sprague-Dawley rats.
\end{abstract}

\section{Introduction}

Based on the results of Kuithan, Stroud, E. Smith, Bradley, Bolk, Edinger and Ingvar [for a review of this literature see Jakob, 1928] and on our own extensive observations, Larsell [Larsell and Jansen, 1967, 1970, 1972] subdivided the cerebellum into a corpus cerebelli and a nodulo-floccular lobe. This concept proved to be valuable for comparative anatomical studies from lower vertebrates to the human, correlating phylogenetic, ontogenetic and functional aspects. According to Larsell [Larsell and Jansen, 1970, 1972], ten transversely oriented lobules respectively folia subdivide the corpus cerebelli and lobus nodulo-floccularis in mammals and birds. These lobules can easily be recognized in a variety of species but for comparative purposes in mammals and birds the cerebellum of the rat and pigeon is most appropriate.

Rats are frequently used as experimental animals in medicine and biology and monographs describe breeding and maintenance under standardized conditions [Farris and Griffith, 1949; Robinson, 1965; Festings and Staats, 1973; Baker et al., 1978, 1980]. A great number

\footnotetext{
'Supported by DFG, La 184/7.
}

of rat strains such as Wistar, Sprague-Dawley, Fischer 344, Long-Evans, Osborne-Mendel, etc. are available. Strains differ in immunological respects [Baker et al., 1978; Annual report, 1977], body size and weight [Riesenfeld, 1981], pathology [Burek, 1978] and longevity [Burek and Hollander, 1980; Masoro, 1980]. In the rat cerebellum, Larsell [1952] already observed variations in the morphology of the lobules but he did not undertake studies on strain-specific differences. After we have examined more than 200 cerebella from rats of different strains [Heinsen, 1977, 1978, 1979, 1981], some of the observed morphological features appeared clearly genetically determined. We began a morphometric analysis to verify this. Data from surface and volume of the granular layer of the vermis of Wistar and Sprague-Dawley rats seemed appropriate to demonstrate such strain-specific differences in cerebellar morphology, which may well be important in cerebellar function.

\section{Material and Methods}

In the present study the cerebella from 6 Wistar (Chbb:THOM) and from 6 Sprague-Dawley (Han:SPRD) rats were used. Details of genetics, breeding, maintenance and pathology for the Wistar rats were published in the Annual Report [1977] of the 'Zentralinstitut für 
Versuchstiere' (Hannover) and by Ueberberg and Lützen [1979] for the Wistar rats. 3 male and female rats 6 months old from each strain were narcotized by intraperitoneal injection of Nembutal and perfusion-fixed with Bouin's fluid [Romeis, 1948] transcardially via the left ventricle. $6 \mathrm{~h}$ after the end of the fixation the cerebella were removed from the skull, weighed on an analytical balance and rostral, dorsal, caudal and basal aspect of the cerebella finally photographed. The cerebellar weight equals after these procedures the fresh weight of the unfixed organ [Stephan et al., 1981].

The cerebella were dehydrated in alcohol, cleared in methylbenzoate and embedded in paraffin [Romeis, 1948]. Complete serial sections from each cerebellum, consisting of 1,500-1,800 sections per cerebellum were made on a Minot rotary microtome. The sections were stained with gallocyanine-chromalum [Romeis, 1948].

Since dehydration in alcohol, embedding in paraffin and sectioning results in considerable and unpredictable shrinkage of tissue we corrected the shrunken volume to fresh volume. If section thickness (t), area (A) and interval (d) between measured serial sections are known, the volume $(\mathrm{V})$ of embedded, sectioned and stained cerebella can be calculated by formula

$$
\mathrm{V}=\mathrm{t} \cdot \mathrm{d} \cdot \mathrm{A}
$$

Section thickness can be estimated with the fine knob of microscopes with an oil-immersion objective and the area of sections by point-counting [Weibel, 1979]. Since we have used every 40th section for these measurements, the interval (d) is 40 . The fresh volume divided by the shrunken volume results in shrinkage factor $\left(\mathrm{S}_{\mathrm{f}}\right)$. In order to obtain values of the living state the microscopic measurements on lengths must by multiplied by ${ }^{3} \sqrt{ } S_{f}$, on surfaces by $\sqrt{ } S_{f}$ and of volumes by $\mathrm{S}_{\mathrm{f}}$.

Beginning with median sections the cursor of an electronic digitizer (MOP AM 03, Kontron) was projected into the microscopic field at $40 \times$ enlargement. We outlined in a first step the upper border of the granular layer which is separated from the molecular layer by the row of Purkinje cells in lobules I-X [Larsell, 1952]. In a second step we traced the total area of the granular layer in lobules $I-X$. We repeated this procedure in every 20 th serial section. Since section thickness (t), interval between serial sections (d), length (l) of the granular layer and area (A) are known, surface (S) and volume (V) of the granular layer can be calculated and corrected to fresh values

$S=1 \cdot t \cdot d \cdot \sqrt{ } S_{f}$

$\mathrm{V}=\mathrm{A} \cdot \mathrm{t} \cdot \mathrm{d} \cdot \mathrm{S}$

Lobules I, IX and X have insignificant hemispherical parts, respectively thin stalks connecting vermian and hemispherical lobules (fig. $2 \mathrm{~d}, \mathrm{~h}$ ). In this case lateral delineation of the lobules was uncomplicated. We stopped measurements in L VI b $+c$ when the medullary ray of L VI b+c became thicker to form the medullary ray of Crus I (fig. 1b), respectively in L VII, when the ansoparamedian fissure appeared in sagittal sections (fig. 1b) and in L VIII when the granular layer thickened by tangential sectioning of the copula (fig. 1b).

All other lobules run continuously without recognizable border into their hemispherical counterpart. In this case we have used the lateral extent of lobules $\mathrm{X}$ as a landmark. The two sagittal planes, which graze the right and left border of $\mathrm{L} X$, pass through the intermediate part of the cerebellum delimiting vermis and hemispheres (fig. 2). A sagittal section through $\mathrm{L} X$ is shown in figure 1b. Few serial sections later, L X has disappeared and then we stopped to trace the outlines of lobules II, III, IV, V and VIa. The quantitative data were tested at the 'Abteilung für Medizinische Dokumentation und Statistik der RWTH Aachen' with a paired t test.
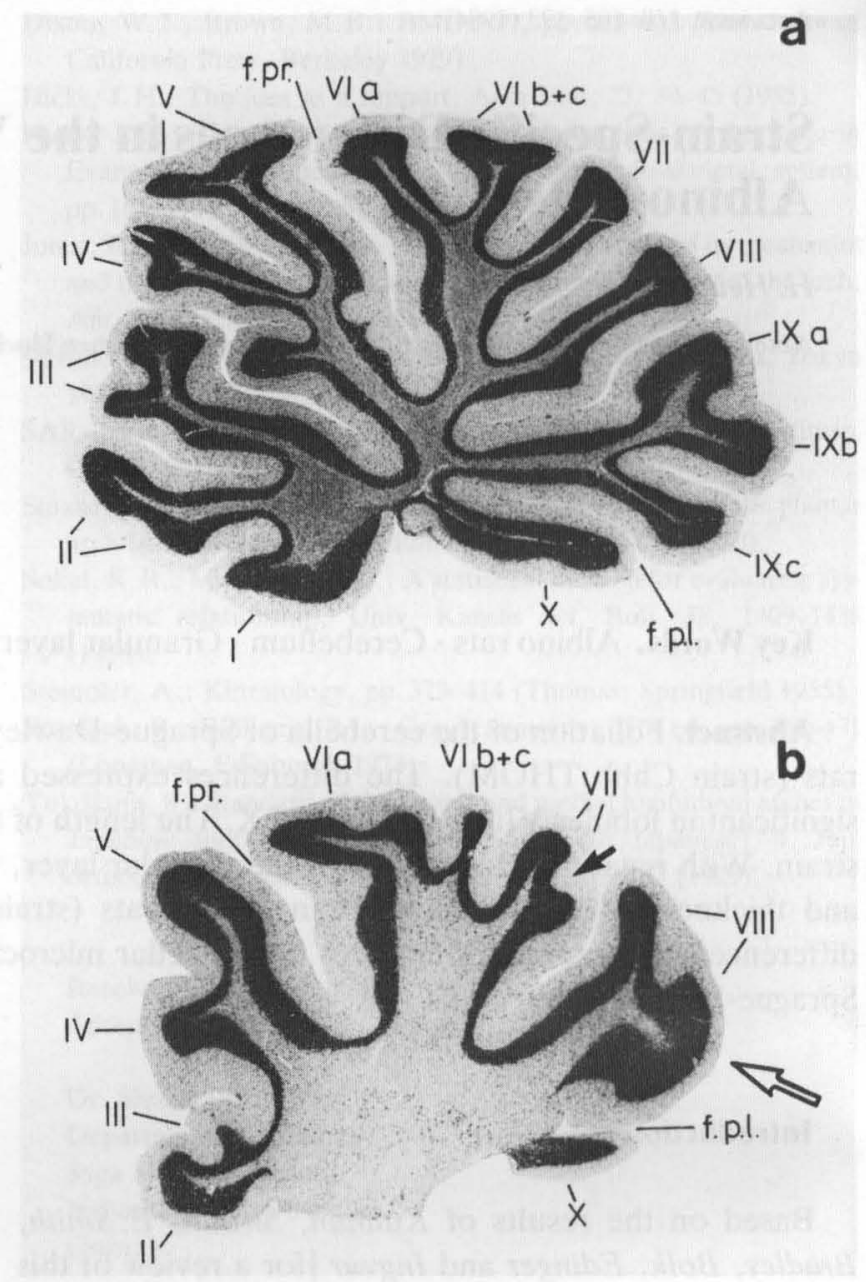

Fig.1. a Median section through the cerebellar vermis of a female Wistar rat (strain Chbb:THOM). b Sagittal section at the vermianhemispheric border (pars intermedia cerebelli). The medullary ray of L VI b+c is extremely thin, the ansoparamedian fissure is indicated by a shallow sulcus in the molecular layer and by a deep depression in the granular layer of H VII (full arrow), the copula (H VIII) appears as a caudally oriented thickening of the granular layer (open arrow). $\mathrm{L} \mathrm{X}$ is tangentially sectioned and few sections further will be no longer visible. Gallocyanine-chromalum. $\times 14$.

\section{Results}

\section{Gross anatomy of Cerebella of Sprague-Dawley and Wistar Rats}

Considerable individual variations existed between the cerebella. Not one of the cerebella was identical in all aspects of lobules, fissures and sulci. Nevertheless, we could recognize some features which were present in Sprague-Dawley and absent in Wistar rats and vice 
a

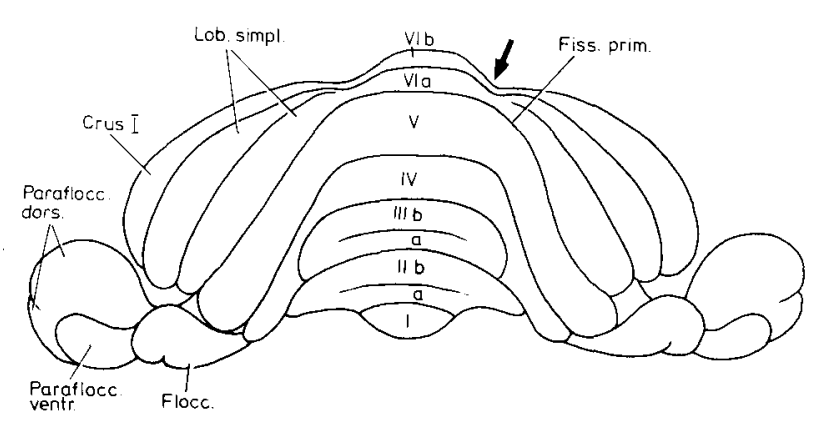

b

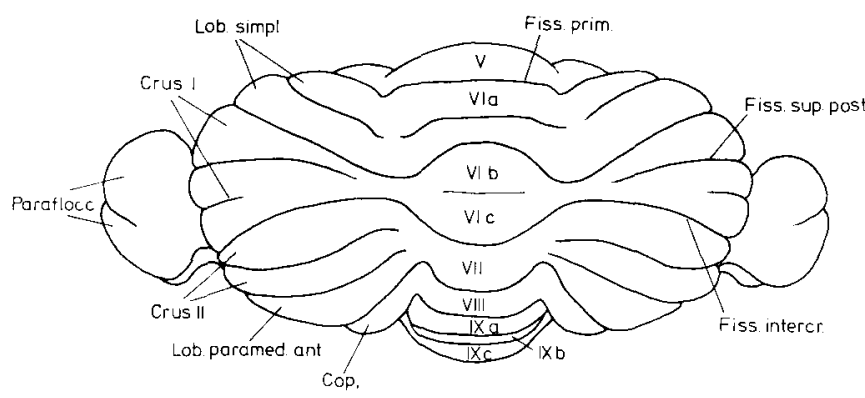

c

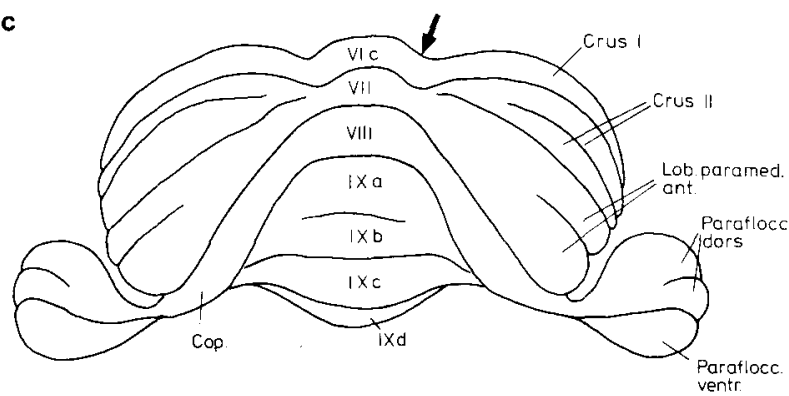

d

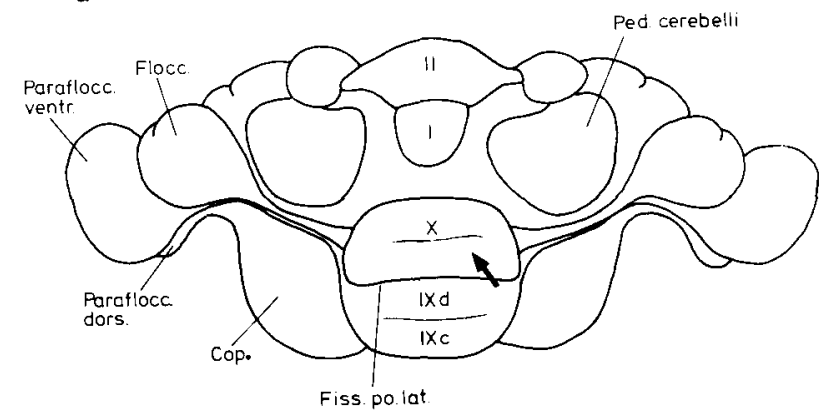

Fig. 2. Rostral (a, e), dorsal (b, f), caudal (c, g) and basal (d, h) aspect of cerebella from Sprague-Dawley (a-d) and Wistar (e-h) rats. Drawings were performed using photographic negatives. The vermis in Sprague-Dawley is smaller, the intermediate parts of the cerebellum appear deeper depressed in this strain (a, c arrows) compared with Wistar (e, $\mathbf{g}$ arrows). A sulcus recognizable from the basal aspect is invariable present in L X of Sprague-Dawley (d, arrow). Compare this with figure 4. Lobule IX frequently possesses a sublobule d in Spra- e
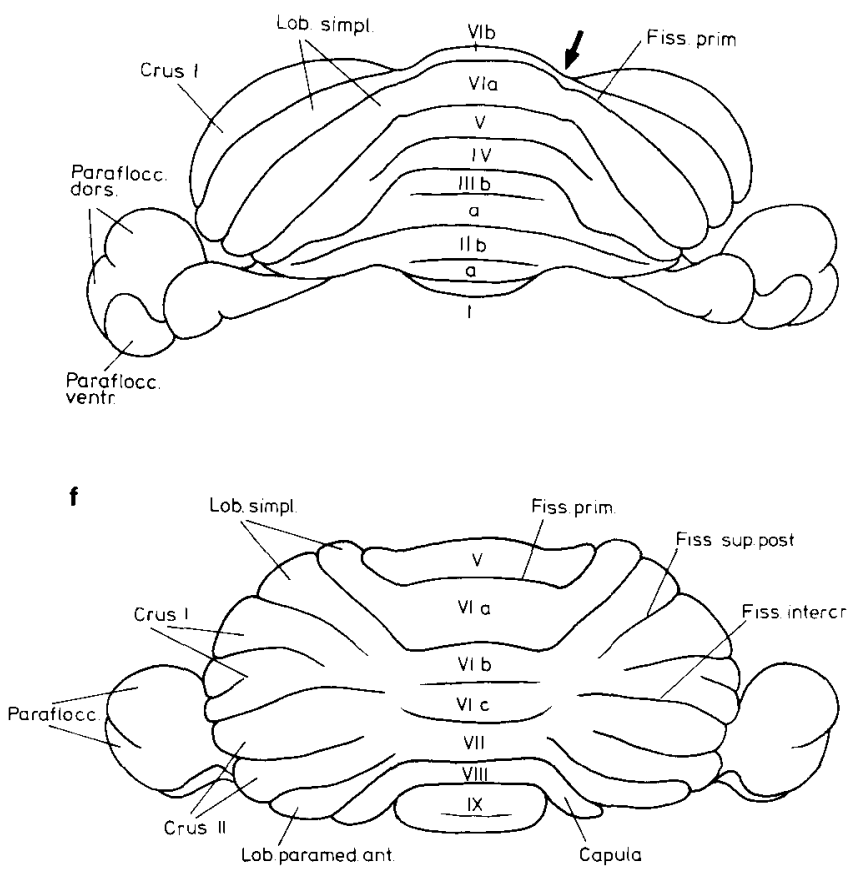

$\mathbf{g}$

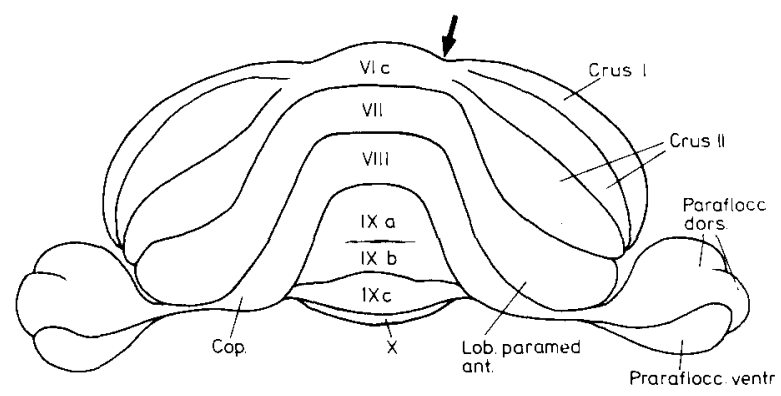

h

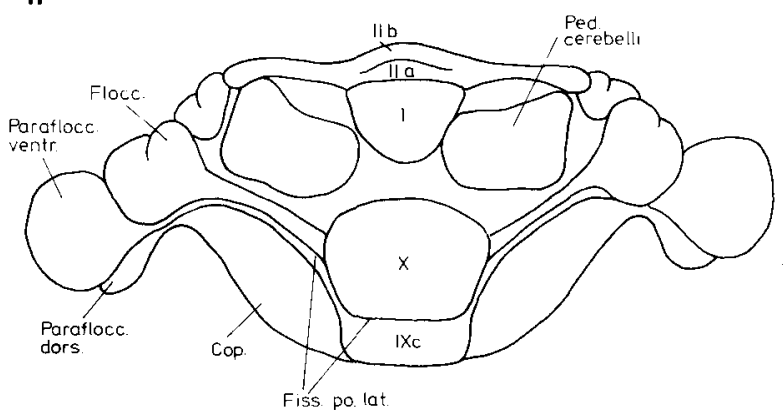

gue-Dawley. For further explanation see text and table I. $\times 5$. Cop. $=$ copula (H VIII); Fiss. intercr. = fissura intercruralis; Fiss. prim. $=$ fissura prima; Fiss.po.lat. = fissura postero-lateralis; Fiss.sup.post. = fissura posterior superior; Lob-paramed. ant. = lobulus paramedianus, anterior and posterior part; Lob. simpl. = lobulus simplex; Paraflocc.dors., ventr. = paraflocculus dorsalis, ventralis; Ped. cerebelli $=$ pedunculi cerebelli . 

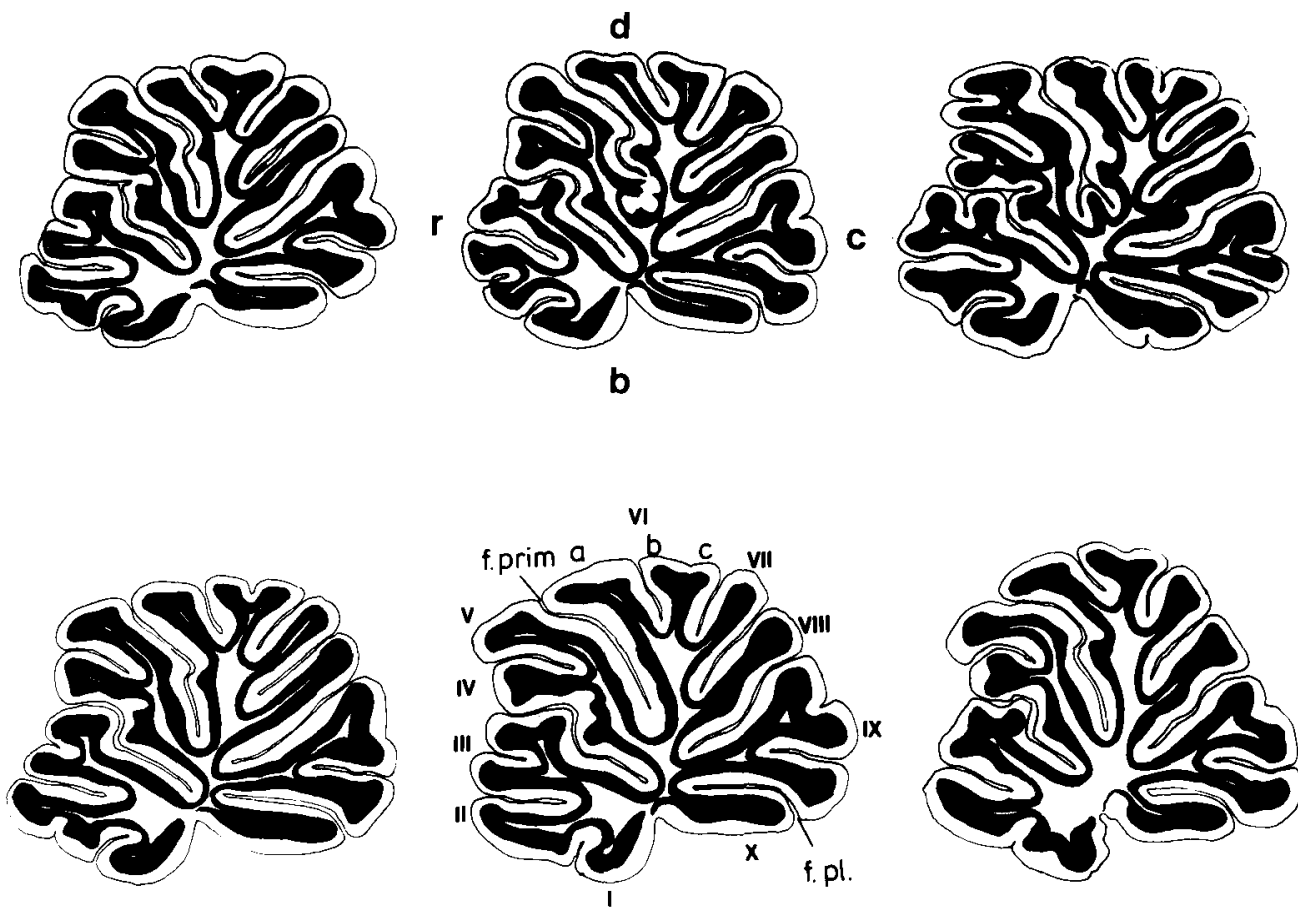

Fig.3. Median sections through the cerebellar vermis of Wistar rats. Camera lucida drawing from gallocyaninechromalum stained sections not corrected for shrinkage. Upper row male, lower row female animals. Fissuration of lobule $X$ is indicated only in 1 animal (upper row, right). Granule cell bridges prevent fissura prima (f.prim.) to reach the depth between $L \mathrm{~V}$ and VI a (upper row, middle). ( $\mathrm{r}=$ rostral; $\mathrm{d}=$ dorsal; $\mathrm{c}=$ caudal; $b=$ basal aspect of the cerebellum. $\times 7$.

Table I. Differences in gross anatomy of cerebella from Sprague-Dawley and Wistar rats (cf. fig. 2)

\begin{tabular}{|c|c|c|c|c|c|c|c|c|}
\hline \multirow[t]{2}{*}{ Strain } & \multicolumn{8}{|l|}{ Structure } \\
\hline & vermis & $\begin{array}{l}\text { intermediate } \\
\text { part }\end{array}$ & hemispheres & $\mathrm{L} I \mathrm{II}+\mathrm{III}$ & L VI & $\begin{array}{l}\text { lobulus para- } \\
\text { medianus }\end{array}$ & LIX & $\mathrm{LX}$ \\
\hline $\begin{array}{l}\text { Sprague- } \\
\text { Dawley }\end{array}$ & $\begin{array}{l}\text { smaller; } \\
\text { elevating } \\
\text { over both } \\
\text { hemispheres }\end{array}$ & $\begin{array}{l}\text { smaller } \\
\text { and more } \\
\text { depressed }\end{array}$ & $\begin{array}{l}\text { lobules in the } \\
\text { anterior lobe } \\
(\mathrm{HIV}+\mathrm{V}) \\
\text { declining at } \\
\text { an acute angle } \\
\text { to the base of } \\
\text { the cerebellum }\end{array}$ & $\begin{array}{l}\text { inconspicuous } \\
\text { hemispheric } \\
\text { extension }\end{array}$ & $\begin{array}{l}\text { L VIa forming } \\
\text { exclusively } \\
\text { lobulus sim- } \\
\text { plex; fissures } \\
\text { running from } \\
\text { hemispheres } \\
\text { through } \\
\text { vermis }\end{array}$ & $\begin{array}{l}\text { anterior } \\
\text { and posterior } \\
\text { lobules present }\end{array}$ & $\begin{array}{l}\text { sublobules } \\
\text { a-d }\end{array}$ & $\begin{array}{l}\text { sulcus present } \\
\text { at the basal } \\
\text { aspect }\end{array}$ \\
\hline Wistar & $\begin{array}{l}\text { running } \\
\text { without } \\
\text { distinct } \\
\text { boundaries } \\
\text { into hemi- } \\
\text { spheres }\end{array}$ & shallow & $\begin{array}{l}\text { slope of H IV } \\
\text { and V less } \\
\text { steep }\end{array}$ & $\begin{array}{l}\text { extending } \\
\text { far laterally } \\
\text { preventing } \\
\mathrm{H} \text { IV }+\mathrm{V} \\
\text { to reach basis } \\
\text { of cerebellum }\end{array}$ & $\begin{array}{l}\text { lobulus sim- } \\
\text { plex formed } \\
\text { by L VI } a+b\end{array}$ & no subdivision & $\begin{array}{l}\text { sublobules } \\
a-c\end{array}$ & sulcus absent \\
\hline
\end{tabular}



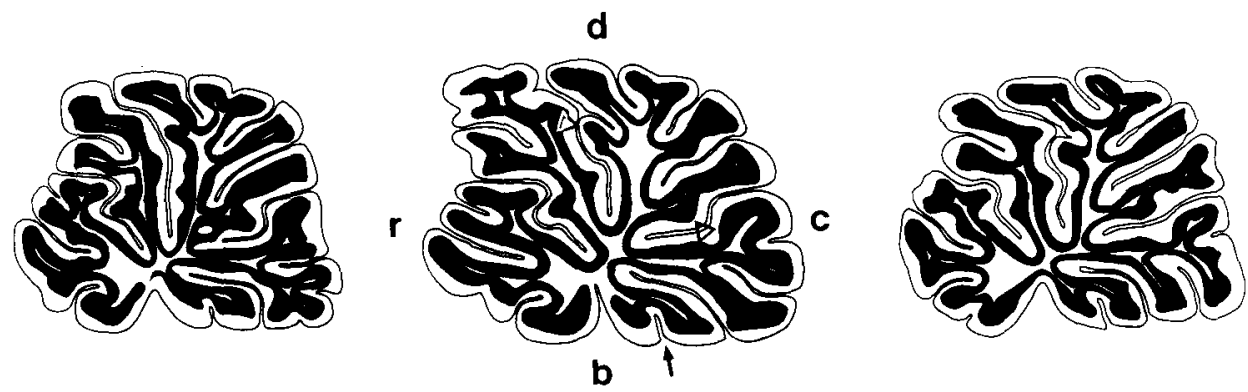

Fig. 4. Median sections through the cerebellar vermis of Sprague-Dawley rats. Technical procedure as in figure 3 . Lobulation is more expressed in this strain, $\mathrm{L} \mathrm{X}$ is subdivided by a constant sulcus (arrow), L IX with additional sublobule d. Sublobules in L VIII facing L IX and $\mathrm{L}$ VI a indicated by triangles. Rostral wall of L VI a is highly irregular.
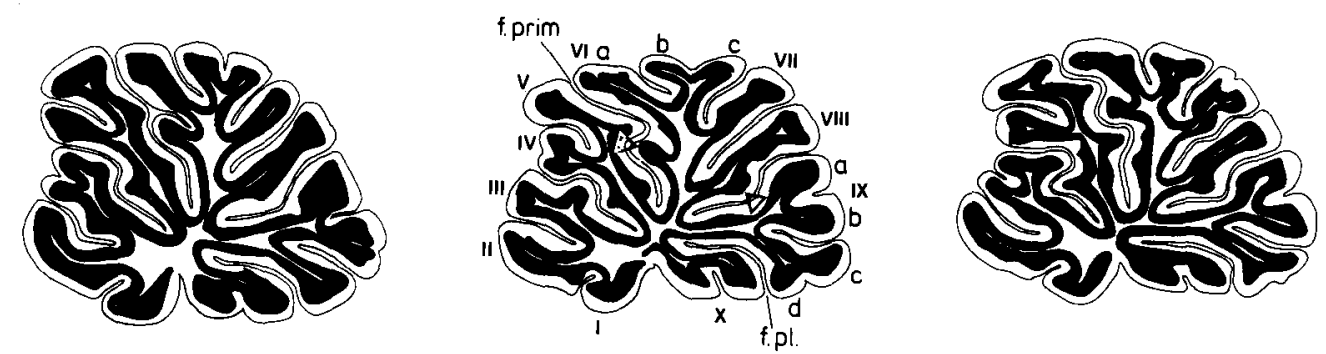

versa. In Sprague-Dawley rats the relief of the vermis was better modelled, standing out against the hemispheres from which it was separated by a small but deeper sulcus, than in Wistar rats (fig. 2a, c, and e, g, arrows). The vermis was smaller in Sprague-Dawley rats whereas in Wistar rats the vermal lobules extended farther into the lateral direction.

Typical differences of some of the cerebellar structures are listed in table I. In summary, fissuration was more complete in Sprague-Dawley rats which was most obvious in lobules of the posterior lobe, especially L IX and $X$.

\section{Length of the Granular Layer in Median Sections}

It was already evident by macroscopic inspection of the complete cerebella that fissuration of cerebellar lobules was more progressed in Sprague-Dawley than in Wistar rats. Median sections through the cerebellar vermis give a better insight into the extent of fissuration and foliation (fig. 3, 4). In Wistar rats we could observe cerebella with rather simple outlines (fig. 3 upper left and lower right). The contours of the granular layer mostly paralleled fissures or sulci of the molecular layer. In Sprague-Dawley rats the outline of the granular layer could be very irregular having no counterpart in sulci of the molecular layer (fig. 4). Differences are summarized in table II.

We have tried to quantify this feature by tracing the contours of the granular layer. The length of the granular layer or degree of foliation was generally higher in Sprague-Dawley rats than in Wistar rats (table III). In lobules of the posterior lobe, L VI a, VIII, IX and X, these differences were statistically significant (fig. 5).

\section{Surface and Volume of Granular Layer}

The total surface of vermal granular layer depends on two factors: the length of the granular layer and the lateral extent of the lobules under consideration. In Sprague-Dawley rats the surface of the granular layers in lobules I-X (fig. 6) was always higher than in Wistar rats but compared with the length of the granular layer (fig. 5) the differences were less pronounced. Only surfaces of the granular layer of lobules $\mathrm{V}$ and IX were significantly higher in Sprague-Dawley rats (fig.6). From these quantitative observations it must be concluded that in Wistar rats the vermal lobules are generally broader in the transverse plane than in SpragueDawley rats. This is in good agreement with macroscopic anatomical findings (fig. 2).

Besides length, lateral extent or breadth the average depth or thickness of the granular layer determines the volume of this stratum. In contrast to the results of length and surface determinations the volume of the granular layer was higher in lobules I, II, III, IV, VI, VII 


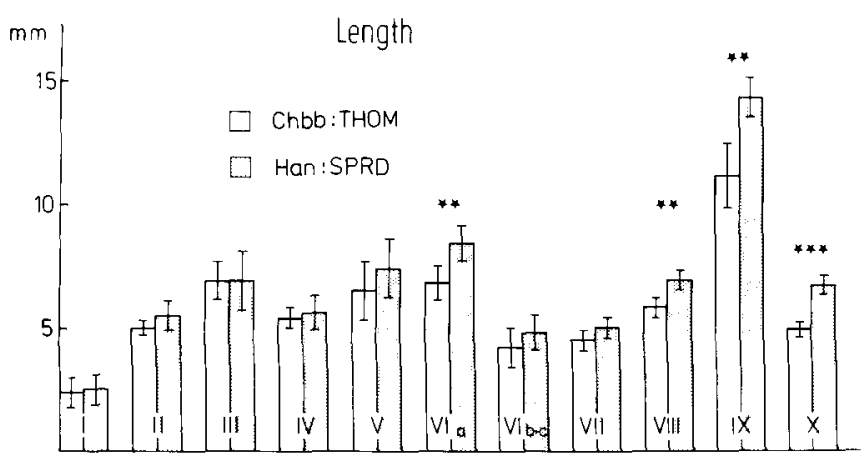

Fig.5. Length of the granular layer in lobules $I-X$ in median sections. Means and standard deviations of the means. ${ }^{* *} \mathrm{p} \leq 0.01$; *** $\mathrm{p} \leq 10^{-4}$. Wistar (strain Chbb:THOM) and Sprague-Dawley (strain Han:SPRD). and $\mathrm{X}$ in Wistar rats. Only lobules V, VIII and IX did not follow this rule. The volume of the granular layer was higher in Sprague-Dawley rats in this case. The differences were statistically significant in lobule IX $(p=0.02)$.

The average thickness or depth of the granular layer can be calculated by division of volume through surface of the granular layer. The average thickness in Wistar rats was $141 \mu \mathrm{m}\left(28 \mathrm{~mm}^{3}: 198.5 \mathrm{~mm}^{2}\right)$ and in SpragueDawley rats it amounted to $126 \mu \mathrm{m}\left(28.2 \mathrm{~mm}^{3}: 223.4\right.$ $\mathrm{mm}^{2}$ ) (table IV, V). These quantitative differences were well illustrated in figures 3 and 4 . The foliation of the granular layer in Sprague-Dawley rats was more progressed but the layer appeared thinner as a whole.

Table II. Comparison of principal morphological differences in median sections (cf. fig. 3, 4)

\begin{tabular}{|c|c|c|c|c|c|c|}
\hline \multirow[t]{2}{*}{ Strain } & \multicolumn{6}{|l|}{ Lobule } \\
\hline & V & $\mathrm{VIa}$ & VII & VIII & IX & $X$ \\
\hline Sprague-Dawley & $\begin{array}{l}\text { granular layer at } \\
\text { the entrance and } \\
\text { depth of the } \\
\text { primary fissure } \\
\text { two distinct } \\
\text { ridges facing } \\
\text { L VIa }\end{array}$ & $\begin{array}{l}\text { contour in the } \\
\text { rostral wall fac- } \\
\text { ing primary fissure } \\
\text { strongly irregular; } \\
\text { ridges and valleys } \\
\text { alternating; } \\
\text { L VId invariably } \\
\text { present }\end{array}$ & $\begin{array}{l}\text { medullary ray } \\
\text { sometimes vaulted; } \\
\text { crests of granular } \\
\text { layer in rostral } \\
\text { and caudal part }\end{array}$ & $\begin{array}{l}\text { medullary ray } \\
\text { vaulted; sub- } \\
\text { lobules on the } \\
\text { caudal part } \\
\text { facing L IX }\end{array}$ & $\begin{array}{l}\text { granular layer } \\
\text { more graceful; } \\
\text { presence of sub- } \\
\text { lobule IXd }\end{array}$ & $\begin{array}{l}\text { sulcus in the } \\
\text { molecular layer }\end{array}$ \\
\hline Wistar & $\begin{array}{l}\text { ridges of granular } \\
\text { layer less pro- } \\
\text { nounced; lower } \\
\text { ridge frequently } \\
\text { forms bridges with } \\
\text { granular layer of } \\
\text { L VIa; primary } \\
\text { fissure as a conse- } \\
\text { quence shallow }\end{array}$ & $\begin{array}{l}\text { less irregular; } \\
\text { L VId sometimes } \\
\text { lacking or deep } \\
\text { in the primary } \\
\text { fissure }\end{array}$ & $\begin{array}{l}\text { medullary ray } \\
\text { straight and } \\
\text { granular layer } \\
\text { simple in outline }\end{array}$ & $\begin{array}{l}\text { medullary ray } \\
\text { generally straight } \\
\text { less foliated } \\
\text { granular layer }\end{array}$ & $\begin{array}{l}\text { only three } \\
\text { sublobules IX a-c }\end{array}$ & $\begin{array}{l}\text { no sulcus or sulcus } \\
\text { very shallow }\end{array}$ \\
\hline
\end{tabular}

Table III. Length of the upper border of granular layer $(\mathrm{mm})$ in median sections of lobules $\mathrm{I}-\mathrm{X}$ : Means and standard deviations of the mean corrected to fresh volume and values of $p$ (paired $t$ test)

\begin{tabular}{|c|c|c|c|c|c|c|c|c|c|c|c|}
\hline \multirow[t]{2}{*}{ Strain } & \multicolumn{11}{|l|}{ Lobule } \\
\hline & I & II & III & IV & V & $\mathrm{VIa}$ & $\mathrm{VI} b+c$ & VII & VIII & IX & $X$ \\
\hline Chbb:THOM & $\begin{aligned} & 3.5 \\
\pm & 0.60\end{aligned}$ & $\begin{aligned} & 5.0 \\
\pm & 0.31\end{aligned}$ & $\begin{array}{r}6.9 \\
\pm 0.85\end{array}$ & $\begin{array}{c}5.4 \\
\pm 0.47\end{array}$ & $\begin{aligned} & 6.5 \\
\pm & 1.26\end{aligned}$ & $\begin{aligned} & 5.8 \\
\pm & 0.70\end{aligned}$ & $\begin{aligned} & 4.3 \\
\pm & 0.89\end{aligned}$ & $\begin{aligned} & 4.5 \\
\pm & 0.45\end{aligned}$ & $\begin{array}{c}5.9 \\
\pm 0.41\end{array}$ & $\begin{array}{r}11.1 \\
\pm \quad 1.39\end{array}$ & $\begin{array}{r}5.0 \\
\pm 0.32\end{array}$ \\
\hline p & 0.78 & 0.03 & 0.92 & 0.38 & 0.22 & 0.002 & 0.31 & 0.08 & 0.001 & 0.003 & $<10^{4}$ \\
\hline
\end{tabular}



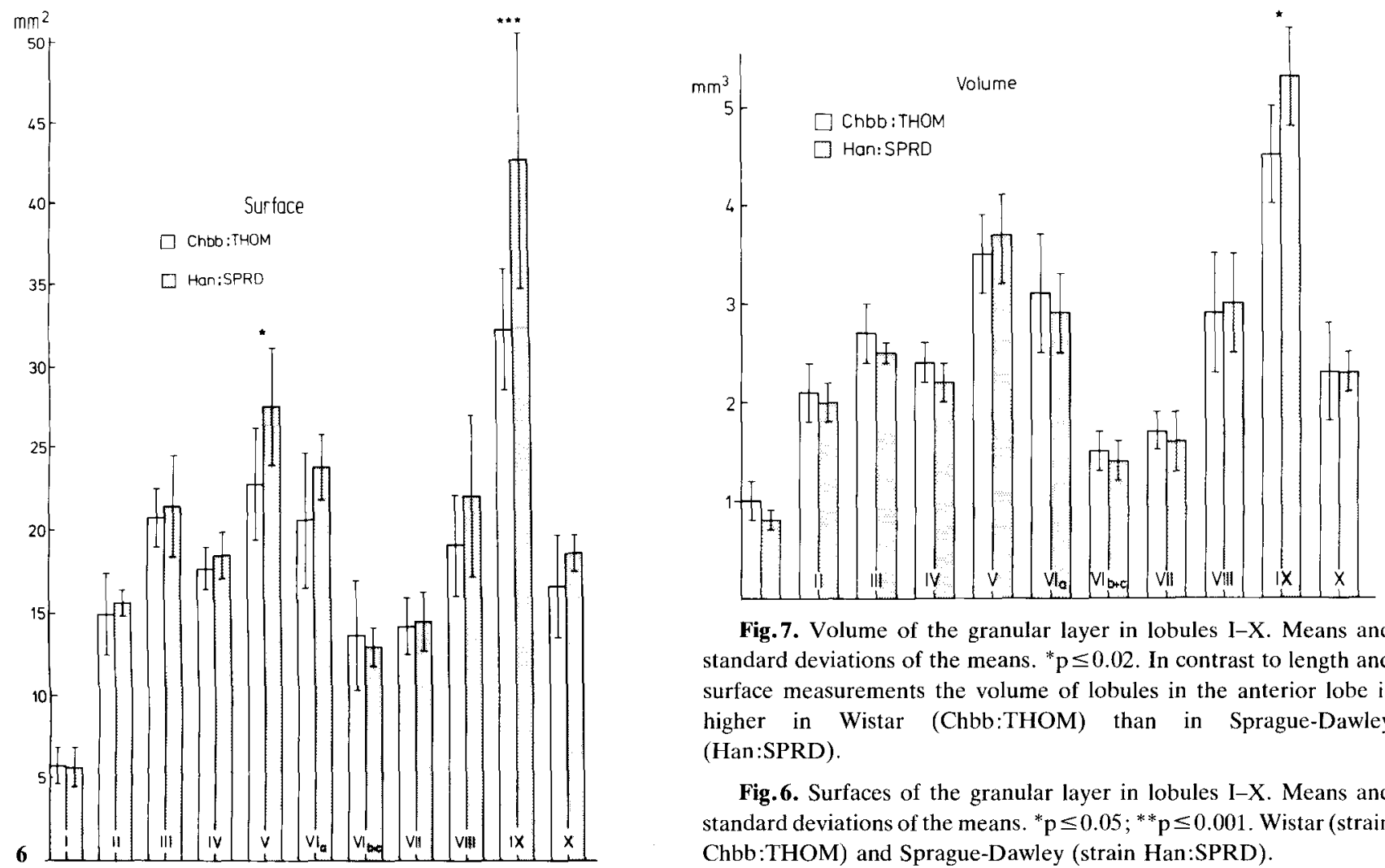

Fig. 7. Volume of the granular layer in lobules I-X. Means and standard deviations of the means. ${ }^{*} p \leq 0.02$. In contrast to length and surface measurements the volume of lobules in the anterior lobe is higher in Wistar (Chbb:THOM) than in Sprague-Dawley (Han :SPRD).

Fig. 6. Surfaces of the granular layer in lobules $I-X$. Means and standard deviations of the means. ${ }^{*} \mathrm{p} \leq 0.05 ;{ }^{* *} \mathrm{p} \leq 0.001$. Wistar (strain Chbb:THOM) and Sprague-Dawley (strain Han:SPRD).

Table IV. Surface of the granular layer $\left(\mathrm{mm}^{2}\right)$ in vermal lobules I-X: means and standard deviations of the means corrected to fresh volume and values of $p$ (paired $t$ test)

\begin{tabular}{|c|c|c|c|c|c|c|c|c|c|c|c|c|}
\hline \multirow[t]{2}{*}{ Strain } & \multicolumn{12}{|l|}{ Lobule } \\
\hline & I & II & III & IV & $\mathrm{V}$ & VIa & $\mathrm{VI} b+\mathrm{c}$ & VII & VIII & IX & $X$ & sum \\
\hline Chbb:THOM & $\begin{array}{c}15.9 \\
\pm 1.13\end{array}$ & $\begin{array}{c}15.1 \\
\pm \quad 2.52\end{array}$ & $\begin{array}{c}20.9 \\
\pm \quad 1.81\end{array}$ & $\begin{array}{r}17.7 \\
\pm \quad 1.31\end{array}$ & $\begin{array}{r}22.8 \\
+\quad 3.42\end{array}$ & $\begin{array}{r}20.6 \\
+\quad 4.14\end{array}$ & $\begin{array}{r}13.7 \\
\pm \quad 3.39\end{array}$ & $\begin{array}{r}14.1 \\
\pm \quad 1.80\end{array}$ & $\begin{array}{c}19.1 \\
\pm \quad 3.15\end{array}$ & $\begin{array}{r}32.1 \\
+\quad 3.75\end{array}$ & $\begin{array}{c}16.5 \\
\pm \quad 3.11\end{array}$ & 198.5 \\
\hline Han:SPRD & $\begin{aligned} & 5.7 \\
\pm & 1.27\end{aligned}$ & $\begin{array}{c}15.7 \\
\pm \quad 0.82\end{array}$ & $\begin{array}{c}21.6 \\
+\quad 3.14\end{array}$ & $\begin{array}{r}18.5 \\
\pm \quad 1.47\end{array}$ & $\begin{array}{c}27.5 \\
\pm \quad 3.70\end{array}$ & $\begin{array}{c}23.9 \\
\pm \quad 2.02\end{array}$ & $\begin{array}{c}12.9 \\
\pm \quad 1.26\end{array}$ & $\begin{array}{r}14.5 \\
\pm \quad 1.83\end{array}$ & $\begin{array}{r}22.1 \\
+\quad 4.91\end{array}$ & $\begin{array}{r}42.5 \\
+\quad 7.95\end{array}$ & $\begin{array}{c}18.5 \\
\pm \quad 1.18\end{array}$ & 223.4 \\
\hline$p$ & 0.83 & 0.67 & 0.50 & 0.32 & 0.04 & 0.20 & 0.72 & 0.76 & 0.13 & 0.001 & 0.30 & \\
\hline
\end{tabular}

Table V. Volume of the granular layer $\left(\mathrm{mm}^{3}\right)$ in vermian lobules I-X: means and standard deviations of the means corrected to fresh volume and values of $p$ (paired t test)

\begin{tabular}{|c|c|c|c|c|c|c|c|c|c|c|c|c|}
\hline \multirow[t]{2}{*}{ Strain } & \multicolumn{12}{|l|}{ Lobule } \\
\hline & I & II & III & IV & V & VIa & $\mathrm{VI} b+\mathrm{c}$ & VII & VIII & IX & $X$ & sum \\
\hline Han:SPRD & $\begin{array}{c}0.9 \\
\pm 0.18\end{array}$ & $\begin{aligned} & 2.0 \\
\pm & 0.26\end{aligned}$ & $\begin{aligned} & 2.5 \\
\pm & 0.17\end{aligned}$ & $\begin{aligned} & 2.3 \\
\pm & 0.28\end{aligned}$ & $\begin{array}{r}3.7 \\
\pm 0.46\end{array}$ & $\begin{array}{c}3.0 \\
\pm 0.42\end{array}$ & $\begin{array}{r}1.4 \\
\pm 0.25\end{array}$ & $\begin{aligned} & 1.7 \\
\pm & 0.34\end{aligned}$ & $\begin{aligned} & 3.0 \\
+ & 0.51\end{aligned}$ & $\begin{array}{r}5.4 \\
\pm 0.55\end{array}$ & $\begin{aligned} & 2.3 \\
\pm & 0.30\end{aligned}$ & 28.2 \\
\hline $\mathrm{p}$ & 0.31 & 0.74 & 0.37 & 0.21 & 0.46 & 0.74 & 0.56 & 0.73 & 0.83 & 0.02 & 0.99 & \\
\hline
\end{tabular}




\section{Discussion}

Strain-specific differences in the morphology of the cerebellum are most obvious in median sections (fig. 3, 4). Lobule $X$ is regularly subdivided by a sulcus which is generally lacking in Chbb:THOM or extremely shallow in Wistar rats (fig. 2d, 4). Lobule IX is frequently subdivided into 4 sublobules a-d in Sprague-Dawley rats and into 3 sublobules in Wistar rats. Such varieties in rats have been described by Larsell [1952] and recently by Eisenman and Noback [1980]. Larsell did not mention the possibility of strain-specific differences, Eisenman and Noback also used Sprague-Dawley rats in their investigations. Bridges of granule cells more frequently connect lobules V and VI a in Wistar. Similar observations have been reported in different strains of rats by Griffin et al. [1980]. The posterior lobe comprising lobules VI-IX is the place exhibiting the greatest morphological variations. This observation which is valid for strain-specific differences holds also true for variations at the phylogenetic level [Jansen and Brodal, 1958]. Deviations from this rule have been reported in mouse [Inouye and Oda, 1980]. In this species variations have been described mainly in the anterior lobe. At variance with Larsell [1952] we could observe subdivisions of lobules I, IV and V (fig. 3, 4).

The differences in shape of the granular layer in median sections are the results of differences in foliation and fissuration. Lauder et al. [1974] have defined foliation as an increase in number and depth of the cerebellar folia, Allen et al. [1981] discriminate foliation and fissuration. The former parameter is quantifiable by the length of the glia limitans covering the molecular layer, the latter by the length of the upper granular (Purkinje) layer. Therefore, foliation in the sense of Allen et al. [1981] is identical with our measurements of the length of the granular layer. Foliation and fissuration are complementary morphogenetic events [Allen et al., 1981] which are the result of interactions between the external granular layer and subcortical structures [Haddara and Nooreddin, 1966; Lauder et al., 1974; Mareš and Lodin, 1970; Rakic and Sidman, 1973] and depend on an intact basal lamina between Bergmann glial end-feet and pial fibroblasts [Sievers et al., 1981]. The foliation in Sprague-Dawley rats is more advanced but the granular layer is thinner. If we consider surface and volume of the granular layer of the complete vermis, differences are less marked between the two strains (fig. 6, 7). The granular layer of Wistar rats compensates depths in foliation by larger lateral extent.
Functional implications of these quantitative differences can at present only be hypothesized. Higher foliation increases the surface of the Purkinje layer. We could indeed report differences in the number of Purkinje cells per $\mathrm{mm}^{2}$ of granular layer in lobule VI $b+c$ in Sprague-Dawley and Wistar rats. But the shape of these lobules is similar in both strains. Lobules $X$ which exhibit most pronounced and constant morphological differences on the other hand do not differ with respect to Purkinje cell density [Heinsen and Heinsen, 1983]. Therefore we conclude that Purkinje cell density per se plays no major role in foliation and fissuration.

Since the granular layer in Wistar rats is thicker, granule cell columns exciting Purkinje cells would be deeper in this strain than in Sprague-Dawley rats. This would have considerable impact on the radial connectivity of parallel fibres with Purkinje cell dendrites [Llinás, 1970, 1982] and differences in the shape of dendritic tree in Purkinje cells can be expected [Pellegrino and Altman, 1979; Altman, 1982]. Besides these supposed differences in the basic cerebellar circuit, additional quantitative differences in climbing and mossy fibre afferences are probable. These afferences are organized in sagittal zones [for literature see Eisenman, 1982]. Since the cerebellar vermis of Sprague-Dawley is smaller than in Wistar rats, the sagittal bands must have different dimensions in both strains.

Quantitative differences in the volume of lobules VI and IX and more voluminous granular layer in lobules of the anterior lobe in Wistar rats make evidence (fig. 7) that mossy fibres and climbing fibres end in different lobules in animals from both strains. Eisenman and Noback [1980] came to similar conclusions during their investigations on the connectivity of lobule IX.

We think it advisable to use in future studies on extrinsic and intrinsic cerebellar connection and on the neurophysiology of the cerebellar cortex only rats from defined inbred strains in order to obtain concordant results.

\section{Acknowledgements}

The authors thank Prof. Dr. H. Ueberberg (Thomae, Biberach a.d. Riss) for providing us with Chbb:THOM rats, Ms. G. Lange for technical and Ms. G. Bock for photographic assistance and Mr. $W$. Graulich for performance of diagrams and drawings.

\section{References}

Allen, C.; Sievers, J.; Berry M.; Jenner, S. : Experimental studies on cerebellar foliation. II. A morphometric analysis of cerebellar fis- 
suration defects and growth retardation after neonatal treatment with 6-OHDA in the rat J.comp.Neurol. 203: 771-783 (1981).

Altman, J.: Morphological development of the rat cerebellum and some of its mechanisms. Exp.Brain.Res. 6: suppl., pp. 8-49 (1982).

Annual Report: Jahresbericht (Zentralinstitut für Versuchstiere, Hannover 1977.

Baker, H.J.; Lindsey, J. R.; Weisbroth S.: The laboratory rat, vol. 1 (Academic Press, New York 1978).

Baker, H. J.; Lindsey, J. R.; Weisbroth, S.: The laboratory rat, vol. 2 (Academic Press, New York 1980).

Burek, J. D.: Pathology of aging rats: a morphological and experimental study of the age-associated lesions in aging $\mathrm{BN} / \mathrm{Bi}$, WAG/Rij and $(W A G \times B N) F_{1}$ rats (CRC Press, West Palm Beach 1978).

Burek, J.D.; Hollander, C. F.: Experimental gerontology; in Baker, Lindsey, Weisbroth, The laboratory rat, vol. 2 (Academic Press, New York 1980).

Eisenman, L. M.: The reticulocerebellar projection to the pyramis and copula pyramidis in the rat: an experimental study using retrograde transport of horseradish peroxidase. J. comp. Neurol. 210: 30-36 (1982).

Eisenman, L.M.; Noback, C. R.: The ponto-cerebellar projection in the rat: differential projections to sublobules of the uvula. Exp.Brain. Res. 38: 11-17 (1980).

Farris, E. J.; Griffith, J.Q.: The rat in laboratory investigation (Lippincott, Philadelphia 1949).

Festing, M.; Staats, J.N.: Standardized nomenclature for inbred strains of rats. Fourth listing. Transplantation 16: 221-245 (1973).

Griffin, W.S.T.; Eriksson, M. A. E.; del Cerro, M. ; Woodward, D. J.; Stampfer, N.: Naturally occurring alterations of cortical layers surrounding the fissura prima of rat cerebellum. J.comp. Neurol. 192: 109-118 (1980).

Haddara, M. A.; Nooreddin, M. A.: A quantitative study on the postnatal development of the cerebellar vermis of mouse. J.comp. Neurol. 128: 245-254 (1966).

Heinsen, H.: Quantitative anatomical studies on the postnatal development of the cerebellum of the albino rat. Anat.Embryol. 151: 201-218 (1977).

Heinsen, H.: Postnatal quantitative changes in the cerebellar uvula of albino rats. Anat.Embryol. 154: 285-304 (1978).

Heinsen, H.: Lipofuscin in the cerebellar cortex of albino rats: an electron microscopic study. Anat.Embryol. 155: 333-345 (1979).

Heinsen, H.: Regional differences in the distribution of lipofuscin in Purkinje cell perikarya. Anat.Embryol. 161: 453-464 (1981).

Heinsen, Y.L.; Heinsen, H.: Regionale Unterschiede der numerischen Purkinje-Zell-Dichte in Kleinhirnen von Albinoratten zweier Stämme. Acta anat. 116: 276-284 (1983)

Inouye, M.; Oda, S.-I.: Strain-specific variations in the folial pattern of the mouse cerebellum. J.comp. Neurol. 190: 357-362 (1980).

Jakob, A.: Das Kleinhirn; in von Möllendorff, Handbuch der mikroskopischen Anatomie des Menschen, vol. 4.1: Nervensystem (Springer, Berlin 1928).

Jansen, J. ; Brodal, A.: Das Kleinhirn; in von Möllendorff, Bargmann, Handbuch der mikroskopischen Anatomie des Menschen, suppl. vol. 4.1 (Springer, Berlin 1958).

Larsell, O.: The morphogenesis and adult pattern of the lobules and fissures of the cerebellum of the white rat. J.comp. Neurol. 97: 281-356 (1952).

Larsell, O.; Jansen, J.: The comparative anatomy and histology of the cerebellum from myxinoids through birds (University of Minnesota Press, Minneapolis 1967).

Larsell, O.; Jansen, J.: The comparative anatomy and histology of the cerebellum from monotromes through apes (University of Minnesota Press, Minneapolis 1970).

Larsell, O.; Jansen, J.: The comparative anatomy and histology of the cerebellum. The human cerebellum, cerebellar connections, and cerebellar cortex (University of Minnesota Press, Minneapolis 1972).

Lauder, J. M. ; Altman, J. ; Krebs, H.: Some mechanisms of cerebellar foliation: effects of early hypo- and hyperthyroidism. Brain Res. 76: 33-40 (1974).

Llinás, R.: Neuronal operations in cerebellar transactions; in Schmitt, The neurosciences: second study program, pp.409-426 (Rockefeller University Press, New York 1970).

Llinás R.: General discussion: Radial connectivity in the cerebellar cortex: a novel view regarding the functional organization of the molecular layer. Exp.Brain Res. 6: suppl., pp. 189-194 (1982).

Mareš, V.; Lodin, Z.: The cellular kinetics of the developing mouse cerebellum. II. The function of the external granular layer in the process of gyrification. Brain Res. 23: 343-352 (1970).

Masoro, E. J.: Mortality and growth characteristics of rat strains commonly used in aging research. Exp.Aging Res. 6: 219-232 (1980).

Pellegrino, L.; Altman, J.: Effects of differential interference with postnatal cerebellar neurogenesis on motor performance, activity level, and maze learning of rats. A developmental study. J.comp. physiol.Psychol. 93: 1-33 (1979).

Rakic, P.; Sidman, R. L.: Organization of cerebellar cortex secondary to deficit of granule cells in Weaver mutant mice. J.comp. Neurol. 152: 133-162 (1973).

Riesenfeld, A.: Age changes of bone size and mass in two strains of senescent rats. Acta anat. 109: 64-69 (1981).

Robinson, R.: Genetics of the Norway rat (Pergamon Press, Oxford 1965).

Romeis, B.: Mikroskopische Technik (Oldenbourg, München 1948).

Sievers, J.; Mangold, U.; Berry, M.; Allen, C. ; Schlossberger, H. G.: Experimental studies on cerebellar foliation. I. A qualitative morphological analysis of cerebellar fissuration defects after neonatal treatment with 6-OHDA in the rat. J.comp. Neurol. 203: 751-769 (1981).

Stephan, H.; Frahm, H. ; Baron, G.: New and revised data on volumes of brain structures in insectivores and primates. Folia primatol. 35: 1-29 (1981).

Ueberberg, H.; Lützen, L.: The spontaneous rate of tumors in the laboratory rat: strain Chbb:THOM (SPF). Drug Res. 29: 1876-1879 (1979).

Weibel, E.; Stereological methods 1 (Academic Press, London-New York 1979).

Received: May 13, 1983

Accepted: June 4, 1983

Dr. med. Helmut Heinsen,

RWTH Aachen,

Abteilung Anatomie,

Melatener Strasse 211,

D-5100 Aachen (FRG) 